\title{
Essay
}

\section{High School Biology Today: What the Committee of Ten Did Not Anticipate}

\section{José Vázquez}

\author{
New York University, New York, NY 10003-1019
}

Submitted July 11, 2005; Accepted August, 19, 2005

Monitoring Editor: Barbara Schulz

\section{HISTORICAL BACKGROUND}

Since the recommendation of biology (or natural history, as it used to be called) in 1893 as part of the high school science curriculum, biology was considered a descriptive subject. In the late 1890s biology consisted of zoology, botany, and physiology. The group that decided on the high school science course configuration was the Committee of Ten. The committee was organized by the National Education Association (NEA) in 1892 to deal with the issue of uniform college entrance requirements. This essay argues that the decision of the Committee of Ten to place biology before chemistry and physics needs to be reexamined. The committee's recommendations are still being implemented over a hundred years later, and the issue of high school science course sequence is currently being debated.

Charles W. Eliot, then president of Harvard University, chaired the Committee of Ten. Eliot had been active in the NEA and was considered a leader in both precollege and higher education. In addition, he was a scientist and considered reasoning power as the central function of the schools (Kleibard, 1995, p. 41).

The rest of the committee consisted of key figures from colleges and high schools. There were nine subcommittees each devoted to different academic subjects of which three were responsible for science. One science subcommittee was for physical science (physics, astronomy, and chemistry), another for natural history (botany, zoology, and physiology), and a third for geography (physical geography, geology, and meteorology).

The general recommendations of the Committee of Ten regarding natural history (biology) were that:

- biology should precede chemistry and physics,

- the usefulness of the laboratory component was emphasized,

- physiology should be taught during the later part of the high school years,

DOI: $10.1187 /$ cbe.05-07-0087

Address correspondence to: José Vázquez (jrv2@nyu.edu).
- the laboratory component should comprise at least $60 \%$ of the class time,

- students should make careful sketches and drawings of observed specimens, and

- the primary purpose of the course was not on memorization but on the acquisition of knowledge and intellectual growth from careful observation of nature.

All subcommittees presented their recommendations, and in 1893 the Committee of Ten submitted a final report, known as Report of the Committee on Secondary School Studies (NEA, 1893 , p. 26, 139-140). The effects of this report were quickly felt as they led to science enrollments that grew exponentially during the next couple of decades to keep up with the committee's recommendations and to deal with massive movements of families from farms to cities as a result of the economic shift from an agricultural to an industrial society (DeBoer, 1991, pp. 49-50; Hurd, 2002, p. 4). These recommendations were not unanimous. Some of the committee members recommended physics to be the first science course in high school. The logic behind this recommendation was that the study of physics was deemed essential to help students develop inferences for phenomena and subject matter, such as chemistry, not easily observed (NEA, 1893, p. 122). On the committee's final recommendations physics was placed after chemistry under the assumption that students would then have better mathematical background and more maturity to deal with physics in a more satisfactory way (p. 123). In addition, biology (called natural history when the report was published) consisted of one semester of botany and one semester of zoology and was a considered a purely descriptive science. Members of the Committee of Ten considered biology a "nature study" (p. 139) closely correlated with the basis of language work, drawing, and other forms of expression. Presumably, the committee members considered biology to be less rigorous than the physical sciences and could thus be required for younger students at the beginning of high school.

The Committee of Ten suggested four different high school sequences: Classical, Latin-Scientific, Modern Languages, and English. The two major distinctions among 
these proposed sequences were the foreign languages required and a slight alteration in the science sequence (see Table 1; NEA, 1893, pp. 46-47).

The report of the Committee of Ten was a reform document that assumed that every child would benefit by receiving a liberal education of the highest quality (Ravitch, 2000, pp. 42-43). The committee's recommendations were met by fierce critics, particularly G. Stanley Hall, president of Clark University in Massachusetts. Hall accused the Committee of Ten's recommendations as being elitist because he favored an educational system based on career choices that students would make before reaching their teens (Ravitch, 2000, p. 46). Hall condemned the idea that all pupils should be taught the same way without any concern for variations among the student body (Kleibard, 1995, p. 12).

Another critic was W. R. Butler, a Massachusetts educator, who disapproved of the same kind of education for all high school students. He also observed that, because most high school graduates were girls, "the higher education of girls is of doubtful utility to the race" (Ravitch, 2000, p. 44).

There are some significant legacies associated with the Committee of Ten. One of the them was the establishment of the College Entrance Examination board in 1900 to offer a common examination for many different colleges (Ravitch, 2000 , p. 47). Another legacy was showing the power of reform by commission. The most recent example is the creation of the National Science Education Standards (National Research Council [NRC], 1996). In this document there is an effort from educational leaders and scientists to promote science education reform. The Standards promote reform by setting national goals and the standards for meeting them. The overall objective of the Standards is to achieve scientific literacy by mastering a set of content standards (DeBoer, 2000 , p. 590). The Standards somewhat mirror the Committee of Ten's recommendations in its focus of science as inquiry and the significance of the history and nature of science to promote a fuller understanding of the subject.

\section{TIME CONSIDERATIONS}

As indicated by Sheppard and Robbins (2002, p. 429), there has been very little discussion about the time allocation for science in U.S. high schools. The Committee of Ten recommended that $25 \%$ of curricular time in each year of high school be devoted to science (NEA, 1893, p. 139). Currently, students spend $\sim 15 \%$ of curricular time in science. This estimate is based on six periods a wk out of $\sim 40$ periods per $w \mathrm{k}$. This is in sharp contrast to the recommendations of the Committee of Ten. The specific details about how this came to be are unclear. What is clear is that our current time allocation is somewhat smaller considering that other countries allow their students to enroll in more than one science course per year, thus leading to greater time allocation. In this regard, I agree with the Committee of Ten's suggestion that, because of the experimental nature of science, more time should be devoted to it in the classroom. Although the instructional time intended for science varies across countries participating in the latest Trends in Mathematics and Science Study (TIMSS), some countries spend up to $32 \%$ of instructional time in science (Martin et al., 2004, p. 189). In the United States the curriculum does not specify the percentage of total instructional time intended for science, except for the benchmarking state of Indiana, which indicated an average instructional time for science of $180 \mathrm{~min}$ per wk (p. 191). This amount of instructional time is comparable to the one in higher achieving countries such as Singapore. However, primary data from TIMSS 2003 need further analysis to understand the implications of instructional practices during the time students spend in science classes. Moreover, allocating more time to science courses would require changes in federal and state policies, thus making such changes extremely difficult to implement in the near future. In addition, national large-scale data would be necessary to support such policy consideration.

The International Baccalaureate (IB) Higher Level Science course lasts 2 yr (IB Diploma Program Guide, 2005). This is far more time than students spend in any of the Advanced Placement (AP) science courses. The AP Biology course description does not address specific time requirements (The College Board, 2001). Given the number of advances in biology over the twentieth century, curricular time in U.S. science courses has not matched the significant increase in the number of topics that biology has experienced over time. These two courses are addressed because they represent the most common alternative for advanced high school biology.

Consider cell biology, for example, which has experienced an exponential growth in terms of depth and number of topics developed since the Committee of Ten Report. Topics such as cell signaling, cancer, transport across the mem-

Table 1. Suggested high school science sequence

\begin{tabular}{|c|c|c|c|c|}
\hline School year & Classical & Latin-scientific & Modern languages & English \\
\hline 9 & Physical geography & Physical geography & Physical geography & Physical geography \\
\hline 10 & Physics & $\begin{array}{l}\text { Physics, botany, or } \\
\text { zoology }\end{array}$ & $\begin{array}{l}\text { Physics, botany, or } \\
\text { zoology }\end{array}$ & $\begin{array}{l}\text { Physics, botany, or } \\
\text { zoology }\end{array}$ \\
\hline \multirow[t]{2}{*}{11} & Astronomy $1 / 2$ yr & Astronomy $1 / 2$ yr & Astronomy $1 / 2$ yr & Astronomy $1 / 2$ yr \\
\hline & Meteorology $1 / 2 \mathrm{yr}$ & Meteorology $1 / 2 \mathrm{yr}$ & Meteorology $1 / 2 \mathrm{yr}$ & Meteorology $1 / 2 \mathrm{yr}$ \\
\hline \multirow[t]{2}{*}{12} & Geology $1 / 2$ yr & Geology $1 / 2$ yr & Geology $1 / 2$ yr & Geology $1 / 2$ yr \\
\hline & $\begin{array}{l}\text { Anatomy, } \\
\text { physiology, } \\
\text { and hygiene } 1 / 2 \mathrm{yr}\end{array}$ & $\begin{array}{l}\text { Anatomy, physiology, } \\
\text { and hygiene } 1 / 2 \mathrm{yr}\end{array}$ & $\begin{array}{l}\text { Anatomy, physiology, } \\
\text { and hygiene } 1 / 2 \mathrm{yr}\end{array}$ & $\begin{array}{c}\text { Anatomy, physiology, } \\
\text { and hygiene } 1 / 2 \mathrm{yr}\end{array}$ \\
\hline
\end{tabular}

From The Committee of Ten Report, 1893. (Modified. Nonscience courses are not shown for clarity.) 
brane, molecular biology, to name a few, can only be covered in high school biology by spending less or no time on other topics. Consequently, high school biology students can only get a survey course that deals with biology at a very superficial level. This type of biology (and overall science) curriculum has been dubbed "a mile wide and an inch deep" (Schmidt et al., 1999, p. 193). This "curricular compression" in biology (and other science courses) represents an attempt to keep up with the continuing explosion of knowledge in biology. W. B. Wood (2002, p. 125) argues that a high school course does not need to be all-inclusive, but when essential topics are omitted students miss an opportunity to relate these topics to a broader perspective. One could argue that other countries cover a smaller subset of topics and cover them in more detail. However, when biology is taught before chemistry and physics, more time might be necessary to explain concepts and/or background material that pertains to chemistry and physics that gives the biological concept a sense of "complete picture." By reversing the biology-chemistry-physics science course sequence, time consideration would not be an issue because biological concepts might be covered in more depth without the need to spend time covering essentials of chemistry and physics that students have not yet covered.

\section{EFFECT ON TEACHING METHODOLOGY}

Currently, there is an ongoing debate about the "Physics First" movement. This policy debate intends to bring physics to students early in high school (American Association of Physics Teachers [AAPT], 2002). The rationale for this policy is to provide students an intellectual foundation for the study of chemistry and biology later in high school. It is the position of AAPT that "physics first has the potential to foster greater scientific literacy and to help integrate physics, chemistry and biology" (AAPT, 2002). However, although an attractive approach in theory, this policy would require significant modifications to our existing curriculum and large-scale changes in teacher preparation and professional development in order to be implemented. By teaching physics to students in ninth grade, the curriculum needs to be modified to teach a subject matter to younger students who do not have the mathematical background that most students who currently enroll in physics have. The policy also needs a more aggressive recruitment of physics teachers or the retraining of teachers from other science disciplines, which may lead to some problems in the way these out-offield teachers present the subject to their students. Similarly, biology curriculum would need to be reframed for older students with an adequate background in physics and chemistry. In addition, biology teachers would need to be more proficient in quantitative aspects of biology that are not usually covered in introductory high school biology such as bioinformatics.

Given the Committee of Ten recommendation that biology should be taught before physics and chemistry, biology teachers confront the dilemma of having to teach a subject that has become so rich over the last few decades. In addition, the typical student population lacks the adequate science background to understand the interdisciplinary nature of biological concepts. Nobel laureate Leon Lederman has been an outspoken advocate of Project ARISE (American Renaissance in Science Education), which argues for reversing the course of high school science courses (Lederman, 1998 , p. 20). ARISE proposes a sequence of physics-chemistry-biology, with physics becoming the foundation for learning chemistry and chemistry becoming a foundation for biology. Lederman argues: “. . . this framework gains further strength from strategies that unify and reinforce content and between each year." One of the reasons given to support biology after physics and chemistry aims to provide a deeper appreciation for the unity and diversity of life.

Another reason is to include some mathematical elements that could enhance the understanding of biology. Some of those mathematical concepts are 3-D geometric modeling, probability, bioinformatics, and statistics for data interpretation.

The number of biology topics that require a reasonable understanding of physics and/or chemistry continues to increase. For example, metabolic reactions, protein synthesis, cell signaling, protein structure, synaptic transmission, cell death, and hormonal regulation represent just a few of those interdisciplinary concepts. Perhaps the most famous integrated concept is the structure and replication of DNA. For high school biology students to gain a true appreciation of the intrinsic details that surround this concept, they must first have an understanding of various types of chemical bonding, enzyme activity, thermodynamics, chemical structure, and electrochemical gradient.

None of these concepts can be fully covered by the biology teacher. Consequently, students end up memorizing plain dry facts about the structure and replication of DNA without being able to integrate it within a larger context such as metabolism or genetics.

\section{DISCUSSION}

Biology continues to be taught at the beginning of high school, before chemistry and physics, in most schools. Consequently, it is regarded as an "easy" science subject that mostly requires memorization of facts. A 2000 national survey (K. D. Wood, 2002) found some prevailing characteristics in the teaching of high school biology: a low proportion of students learning how to communicate science (39\%); only a $27 \%$ emphasis on learning about the relationship of science, technology, and society; a small amount of time spent evaluating arguments based on scientific evidence (23\%); and a significant amount of time (56\%) learning important terms and facts of science (p. 15). In addition, only $12 \%$ is spent learning about the history and nature of science.

These findings stand in contrast to what the Standards emphasize (NRC, 1996):

- Learning how to communicate ideas in science effectively;

- Learning about the relationship between science, technology, and society;

- Learning to evaluate arguments based on scientific evidence;

- Learning about the applications of science in business and industry; and

- Learning about the history and nature of science. 
The Committee of Ten recommended $\sim 60 \%$ of laboratory work in high school science courses. The 2000 national survey found that more instructional time is devoted to lecture than any other activity, both for biology and for the other sciences (K. D. Wood, 2002, p. 19). Across all biology lessons, only $26 \%$ of instructional time is spent in hands-on or laboratory activities. These activities tend to be primarily shortterm exercises that do not mirror scientific investigations.

Another aspect of biology recommended by the Committee of Ten is the importance of field work as an aspect of learning biology. In the 2000 national survey only 75\% of high school biology classes include participation in field work (p. 20). This is somewhat disappointing considering that field activity is one of the few opportunities for students to experience real-world biology. However, there are some logistic issues associated with the relatively small amount of time doing investigations. For instance, time, money, and safety are constraints that limit the amount of lab work done by students in the biology classroom. The significant amount of field work, $\sim 60 \%$, recommended by the Committee of Ten (NEA, 1893, p. 139) may interfere with instructional time in other subjects and extracurricular activities, which one could argue are as significant as instructional time in science.

A recent report (NRC, 2005) examines the prevailing issues related to science laboratory instruction in U.S. high schools. Among the problems listed are research gaps and lack of consensus on how to define these labs or their purpose. In addition to the logistic issue described in the previous paragraph, laboratory experiences in high school science courses do not follow effective principles of science instruction such as the following (p. 4):

- Design science lab experiences with clear learning outcomes in mind

- Thoughtfully sequence lab experiences into science instruction

- Integrate learning science content and learning about the processes of science

- Incorporate ongoing student reflection and discussion.

One of the factors listed for such inconsistencies observed in lab instruction is a gap in the knowledge of science teachers, which makes it difficult to translate lab activities into meaningful science lessons (p. 2). The report found an overall lack of coherence in the majority of laboratory activities and failure to provide students with opportunities to do "real science" such as using tools, learning data collection techniques, developing models, and designing experiments (pp. 2-3). Insufficient data due to lack of available studies makes it more difficult establish what needs to be done to improve the status quo of laboratory instruction in high school science courses. Improving laboratory instruction would require a systemic reform that involves more adequate teacher preparation, better equipment and school facilities, more teamwork among science teachers, and inclusion of a laboratory component in assessment instruments (pp. 3-10). With this in mind, it is somewhat unrealistic to propose more field and laboratory activities if these do not provide a coherent and adequate framework for understanding science. A research agenda is needed to provide adequate evidence as to what needs to be done to improve laboratory instruction. In particular, studies should address the following: the experiences needed by high school students, adequacy of proposed lab activities, suitability for diverse learners, and the availability of professional development support services for teachers to master the laboratory activities. Research may also incorporate data from cross-national studies supporting the proposed agenda.

Finally, laboratory activities should integrate use of technology in order to provide a stepping stone to the increasing technological demands that students must face while in school and after finishing high school.

The current status of high school biology is not surprising considering the young age of most biology students and their lack of a solid science background in the physical sciences. If the original recommendations of the Committee of Ten had been implemented, science education history in the United States would be different. As Sheppard and Robbins argue (2002, p. 431), the present structure of high school science education is more of a historical accident. Data from the National Center for Education Statistics (2000) indicate that overall high school science achievement in our country has declined. In addition, data from the TIMSS indicate that in the United States different students have different access - and lack of access — to educational content (Schmidt et al., 1999, pp. 198-199). The higher levels of achievement indicated in many TIMSS countries were not characterized by differential access, which questions the effectiveness of how we teach science to our students. This is a matter of concern if we wish to remain competitive in a global economy. The Committee of Ten report may be considered an "old document" by many contemporary players in education, but it holds an important place in science education history as a reform document that brought science teaching and learning to the forefront of education. More than 100 years after the report was issued, most of our schools still offer high school science courses in the sequence suggested by the Committee of Ten. Science education is still debating what criteria should define the coherence of our science curriculum to lead to scientific literacy for all. If there is one lesson to be learned from my argument, it is that the Committee of Ten did not anticipate that more than 100 years later its recommendations would continue to be a matter of dispute and that one of the subjects proposed to improve the learning experience of our high school students is still a subject of plasticity in the reform efforts during the twenty-first century.

\section{REFERENCES}

American Association of Physics Teachers (2002). AAPT Statement on Physics First. http://www.aapt.org/Policy/physicsfirst.cfm (accessed 29 July 2005).

DeBoer, G. E. (1991). A History of Ideas in Science Education: Implications for Practice, New York: Teachers College Press.

DeBoer, G. E. (2000). Scientific literacy: another look at its historical and contemporary meanings and its relationship to science education reform. J. Res. Sci. Teaching 37, 582-601.

IB Diploma Program Guide. (2005). Available at http://www. ibo.org (accessed 18 June 2005).

Hurd, P. D. (2002). Modernizing science education. J. Res. Sci. Teaching 39, 3-9. 
Kleibard, H. M. (1995). The Struggle for the American Curriculum: 1893-1958, New York: Routledge.

Lederman, L. M. (1998). Three-year high school sequence core curriculum framework. http://lss.fnal.gov/archive/1998/tm/TM2051.pdf (accessed 18 June 2005).

Martin, M. O., Mullis, I.V.S., Gonzalez, E. J., and Chrostowski, S. J. (2004). TIMSS 2003 International Science Report. Boston: International Association for the Evaluation of Educational Achievement (IEA).

National Center for Education Statistics (2000). NAEP: The Nation's Report Card 2000. Science Highlights. http://nces.ed.gov/ nationsreportcard/science (accessed 18 June 2005).

National Education Association (1893). Report of the Commission on Secondary School Studies. Washington, DC. (This is commonly known as The Committee of Ten Report.)

National Research Council (1996). National Science Education Standards, Washington, DC: National Academy Press.

National Research Council (2005). America's Lab Report: Investigations in High School Science. Committee on High School Science Laboratories: Role and Vision, ed. S. R. Singer, M. L. Hilton, and H.
Schweingruber, Board on Science Education, Center for Education, Division of Behavioral and Social Sciences and Education. Washington, DC: The National Academies Press.

Ravitch, D. (2000). Left Back: A Century of Failed School Reforms, New York: Simon \& Schuster.

Schmidt, W. H., McKnight, C. C., Cogan, L. S., Jakwerth, P. M., and Houang, R. T. (1999). Facing the Consequences: Using TIMSS for a Closer Look at U.S. Mathematics and Science Education, Dordrecht, The Netherlands: Kluwer Academic Publishers.

Sheppard, K., and Robbins, D. M. (2002). Lessons from the Committee of Ten. Physics Teacher 40, 426-431.

The College Board (2001). Advanced Placement Course Description: Biology, New York. http://www.collegeboard.com/ap (accessed 18 June 2005).

Wood, K. D. (2002). Status of High School Biology Teaching. 2000 National Survey of Science and Mathematics Education. http:// 2000survey.horizon-research.com (accessed 16 June 2005).

Wood, W. B. (2002). Advanced high school biology in an era of rapid change: a summary of the Biology Panel Report from the NRC Committee on Programs for Advanced Study of Mathematics and Science in American High Schools. Cell Biol. Educ. 1, 123-127. 